\title{
Rевенст автісі: : Study of relationship between profile of awardee farmer with cropping pattern followed by awardee farmers in Marathwada region
}

\section{A.R. MERGEWAR, P.R. DESHMUKH AND N.D. DESHMUKH}

Article Chronicle : Received : 22.06.2017;

Revised :

21.09.2017;

Accepted :

08.10 .2017

\section{KeY Words :}

Cropping pattern, Relationship, Awardee farmers

Author for correspondence :

\section{A.R. MERGEWAR}

Department of

Extension Education,

Vasantrao Naik

Marathwada Krishi

Vidyapeeth, PARBHANI

(M.S.) INDIA

See end of the article for authors' affiliations
SUMMARY : The present study was conducted with specific objectives in Marathwada region. The relationship of the characteristics of the awardee farmers namely farming experience, land holding, area under irrigation, occupation, annual income, training received, award received, information seeking behaviour, management orientation and productivity level with cropping pattern was found to be positive and significant. It was however, observed that the relationship between age and education of the respondents and the cropping pattern was non-significant.

How to cite this article : Mergewar, A.R., Deshmukh, P.R. and Deshmukh, N.D. (2017). Study of relationship between profile of awardee farmer with cropping pattern followed by awardee farmers in Marathwada region. Agric. Update, 12(4): 653-656; DOI : 10.15740/HAS/AU/12.4/653-656. 